\title{
Prevalence and factors associated with underweight among Brazilian older adults
}

\author{
Prevalência e fatores associados ao baixo peso em idosos brasileiros
}

Priscila Maria Stolses Bergamo Francisco (https://orcid.org/0000-0001-7361-9961) ${ }^{1}$

Daniela de Assumpção (https://orcid.org/0000-0003-1813-996X) ${ }^{1}$

Flávia Silva Arbex Borim (https://orcid.org/0000-0001-7316-1145) ${ }^{1}$

Deborah Carvalho Malta (https://orcid.org/0000-0002-8214-5734) ${ }^{2}$

${ }^{1}$ Departamento de Saúde Coletiva, Faculdade de Ciências Médicas. Universidade Estadual de Campinas. R. Tessália Vieira de Camargo 126, Cidade Universitária. 13083-887 Campinas SP Brasil. primaria@fcm.unicamp.br ${ }^{2}$ Escola de Enfermagem, Universidade Federal de Minas Gerais. Belo Horizonte MG Brasil.
Abstract The aim of this study was to estimate the prevalence of underweight among older adults according to socio-demographic characteristics in different regions of Brazil as well as determine associated contextual and individual factors. Cross-sectional population-based study with older adults ( $\geq 65$ years) interviewed by telephone survey in 2014. The body mass index was calculated based on weight and height. Associations were determined using Pearson's chi-square test, considering a 5\% significance level. Adjusted prevalence ratios were estimated using multilevel Poisson regression. Mean age was 73.3 years and the prevalence of underweight was 15.6\% (95\%CI: 14.1$17.1 \%)$. Higher prevalence rates of underweight were found among women, individuals aged $\geq 80$ years, smokers and those who reported the regular consumption of beans. The prevalence rate of underweight was lower among those who reported abusive alcohol intake and those with a medical diagnosis of hypertension. The northern region of the country had the highest prevalence of underweight after adjusting for associated individual factors. The findings demonstrate the subgroups with higher prevalence rates of underweight that demand greater attention from the health services in terms of recovering of an adequate nutritional status.

Key words Nutritional status, Body mass index, Health of the elderly, Health survey, Brazil
Resumo O objetivo foi estimar a prevalência de baixo peso em idosos, segundo características sociodemográficas nas regiões do país e verificar os fatores contextuais e individuais associados. Estudo transversal de base populacional com idosos ( $\geq$ 65 anos) entrevistados pelo Vigitel 2014. O Índice de Massa Corporal foi calculado com o peso e estatura referidos. Verificaram-se as associações pelo teste Qui-quadrado de Pearson, considerando-se um nível de significância de 5\%. Razões de prevalência ajustadas foram obtidas por meio de regressão de Poisson multinível. A média etária dos idosos foi de 73,3 anos e a prevalência de baixo peso foi de 15,6\% (IC $\left.{ }_{95 \%}: 14,1-17,1\right)$. Verificaram-se prevalências mais elevadas de baixo peso no sexo feminino, nos que tinham $\geq 80$ anos, nos fumantes e naqueles que referiram ingerir feijão regularmente. A prevalência de baixo peso foi menor nos indivíduos com consumo abusivo de álcool e diagnóstico médico de hipertensão arterial. A região Nordeste apresentou maior prevalência de baixo peso, mesmo após ajuste pelos fatores individuais associados ao baixo peso. Os resultados revelam os subgrupos com maiores prevalências de baixo peso e que demandam maior atenção dos serviços de saúde no monitoramento e recuperação do estado nutricional.

Palavras-chave Estado nutricional, Índice de massa corporal, Saúde do idoso, Inquérito de saúde, Brasil 


\section{Introduction}

Ageing is a process that involves genetic factors and is influenced by disease, diet and lifestyle ${ }^{1}$. Moreover, the natural physiological and metabolic changes that accompany ageing can affect the health and nutritional status of older adults ${ }^{2,3}$. The older population is more prone to nutritional deficit due to factors such as living alone, widowhood, the loss of identity and loss of social roles as well as less food intake due to physical limitations, difficulty chewing and changes in the sense of taste ${ }^{2,4,5}$. Chronic diseases, cognitive deterioration, depression, anxiety and the use of medications can also favor weight loss ${ }^{2,4,5}$.

In the Brazilian older population, the prevalence of underweight (body mass index [BMI] < $22 \mathrm{~kg} / \mathrm{m}^{2}$ ) is $19.9 \%$ and $18.2 \%$ among men and women, respectively, with higher rates found in those with an advanced age, those living in the northeastern and central regions of the country, those living alone and those with lower schooling and income ${ }^{6}$. In a study conducted with community-dwelling older adults ( $\geq 65$ years) in seven Brazilian cities, the prevalence of underweight was $12.0 \%$ and was higher among those aged $\geq$ 80 years, former and current smokers, those who reported a loss of appetite and those classified as frail or pre-frail ${ }^{7}$. A systematic review of longitudinal studies found that age, polypharmacy, constipation, dementia, poor appetite and swallowing problems were among the risk factors that lead to malnutrition in older adults ${ }^{8}$. Moreover, being underweight increases the risk of death'.

Using data from a cohort study conducted in Canada, researchers found that a BMI $\leq$ $22.5 \mathrm{~kg} / \mathrm{m}^{2}$ increased the risk of death 1.48 -fold (95\% confidence interval [CI]: 1.36 to 1.61 ) in women and 1.26 -fold (95\% CI: 1.04 to 1.52 ) in men $^{10}$. Older adults have particular characteristics that require a broad restructuring of healthcare services to meet the new demands imposed by this growing population ${ }^{11}$. Thus, the aim of the present study was to estimate the prevalence of underweight in Brazilian older adults and investigate associations with socio-demographic characteristics, health behaviors and morbidity in different regions of the country.

\section{Methods}

A population-based, cross-sectional study was conducted using data from the Surveillance System of Risk and Protection Factors of Non-
Communicable Diseases by Telephone Survey (Vigitel, 2014) involving a sample of community-dwelling older adults with at least one telephone line. Records were used of individuals aged 65 years or older residing in Brazilian state capitals and the Federal District in 2014.

The Brazilian Ministry of Health has conducted the Vigitel survey annually since 2006, for which a probabilistic sample is selected in three stages. The first stage consists of a systematic randomized selection of five thousand telephone lines divided into subsamples of 200 lines each, reproducing the same proportion of lines per district of the city or per area code. The second step is performed simultaneously with the interviews and includes the identification of active residential landline telephones considered eligible for the system. Business lines, out-of-service lines and numbers for which there is no answer after six calls at different times on different days are excluded. In the third stage, individuals are randomly selected from the list of eligible lines among all adults ( $\geq 18$ years of age) residing in the home ${ }^{12}$.

For each year of the survey, a minimum sample of 2000 interviews per city is considered, enabling the estimation of the frequency of risk factors for chronic diseases in the adult and elderly population with $95 \%$ confidence intervals (95\% CI) and maximum error of two percentage points.

Weighted factors are used to compensate for the bias of the non-universal coverage of landline telephones. The estimates are adjusted to the population using post-stratification weighting, which is calculated based on 36 categories per gender (male or female), age group (18-24, 25$34,35-44,45-54,55-64$ or $\geq 65$ years) and schooling (none/incomplete elementary school, complete elementary school/incomplete high school, complete high school/incomplete university or complete university). The post-stratification weighting of each individual in the sample is calculated using the rake method. Further information on the sampling design and interview procedures are published elsewhere ${ }^{12}$.

The Vigitel survey is performed with a questionnaire addressing socio-demographic characteristics, health-related behaviors, health conditions, etc. The prevalence rates estimated in the present study were calculated based on the BMI, with $<22 \mathrm{~kg} / \mathrm{m}^{2}$ considered indicative of underweight $^{13}$. Both weight and height were self-reported by the interviewees. Hot deck imputation was performed for missing data, considering age, 
gender, schooling and race/skin color as well as non-responses regarding weight and height. The model resulting from this investigation enables the creation of respondent and non-respondent groups with similar characteristics for predictive variables of the non-responded condition. An individual is then randomly selected from each group for the replication of his/her weight and height data for a non-respondent in the same group $^{12}$.

In the present study, the independent variables were geographic region of the country (North, Northeast, Central West, South or Southeast), gender (male or female), age group (65 to 69 , 70 to 74,75 to 79 or $\geq 80$ years), race/skin color (white, brown, black or yellow/indigenous), marital status (married/in a stable union, single, widowed or separated/divorced) and schooling ( 0 to 8,9 to 11 or $\geq 12$ years of study). The behavioral variables were smoking (non-smoker, ex-smoker or current smoker), binge drinking ( $\geq$ five alcoholic beverages for men and $\geq$ four for women on one occasion in the previous 30 days [yes or no]) and practice of physical activity (active or inactive). With regard to food intake, the regular consumption (five or more days per week) of vegetables, fruit, consumption of fatty chicken meat, whole milk and beans as well as the habit of regularly (seven or more times per week) replacing main meals with snacks were evaluated. Health status was investigated based on self-rated health (very good/good, fair or poor/very poor) and the presence of self-reported chronic diseases (hypertension, diabetes and dyslipidemia [yes or no]).

Prevalence rates of underweight and respective $95 \%$ CIs were estimated for Brazilian older adults residing in the different regions of the country according to socio-demographic variables. Associations between underweight and the selected variables were determined using Pearson's chi-square test with second-order correction (Rao \& Scott), considering a 5\% significance level. Crude prevalence ratios (PRs) were estimated for socio-demographic characteristics, health-related behaviors, frequency of food intake, self-rated health and self-reported health conditions. PRs were then adjusted for gender and age. A mixed-effects (multilevel) Poisson model was used to evaluate the consistency of the individual variables and regional differences with regard to underweight. Beginning with the presupposition that older adults who live in the same region tend to have similar characteristics and behaviors (socioeconomic status, cultural factors, habits, etc.) with regard to health problems and given the socio-demographic, economic and cultural heterogeneity among the regions of Brazil, this variable was considered a random effect in order to measure the influence that the region of residence may exert on the nutritional profile, particularly underweight.

In the final model, PRs were adjusted by variables situated on the same level of determination (individual) and the context variable. Finally, the independent effect of each region on underweight was determined by adjusting the context variable (region) by variables that represent individual characteristics associated with the outcome. The analyses were performed with the aid of the Stata 12.0 program (Stata Corp., College Station, USA).

All individuals received clarifications regarding the objectives of the study during the telephone contact and written consent was replaced with oral consent. This study received approval from the National Human Research Ethics Committee of the Brazilian Ministry of Health under process number 355.590 on June $26^{\text {th }}, 2013$.

\section{Results}

Data were analyzed from 8417 older adults ( $\geq 65$ years) residing in the five regions of Brazil. Mean age was 73.3 years ( $95 \%$ CI: 73.0 to 73.6 years). The prevalence of underweight $\left(\mathrm{BMI}<22 \mathrm{~kg} / \mathrm{m}^{2}\right)$ was estimated at $15.6 \%$ (95\%CI: 14.1 to $17.1 \%)$.

Table 1 displays the prevalence rates of underweight according to socio-demographic characteristics and macro-region. Statistically significant differences were found between the northeastern and southern regions. For the female gender, the prevalence of underweight was $19.9 \%$ (95\%CI: 17.4 to 22.5 ) in the Northeast and $14.2 \%$ (95\%CI: 11.8 to $17.1 \%)$ in the South. With regard to race/skin color, the prevalence of underweight among whites was higher in the Northeast (20.3\%; 95\%CI: 16.7 to $24.5 \%)$ than the South $(13.0 \%$; $95 \%$ CI: 10.7 to $15.6 \%)$ and Southeast (12.9\%; 95\%CI: 10.0 to $16.5 \%$ ).

The prevalence of underweight was significantly higher among women after controlling for age and higher among individuals aged $\geq 80$ years after controlling for gender. The prevalence also remained high in the northeastern region after controlling for these variables (Table 2).

Table 3 displays the prevalence rates of underweight according to health-related behaviors, 
food intake frequency, self-rated health and self-referred adverse health conditions. Higher prevalence rates were found among smokers ( $\mathrm{PR}=$ 1.59 ; 95\%CI: 1.10 to 2.27 ) and those who reported the regular consumption of beans $(\mathrm{PR}=1.24$; 95\%CI: 1.02 to 1.50 ). Lower prevalence rates of underweight were found among those who reported binge drinking ( $\mathrm{PR}=0.58$; 95\%CI: 0.34 to 0.97 ) and those who reported having hypertension, diabetes and dyslipidemia.
Table 4 displays the results of the multilevel analysis of factors associated with underweight. Higher PRs were found among women, individuals aged 80 years or older, smokers and those who reported consuming beans in comparison to the reference categories. In contrast, PRs were significantly lower among those who reported binge drinking ( $\mathrm{PR}=0.58$; 95\%CI: 0.34 to 0.96 ) and those with hypertension $(\mathrm{PR}=0.59 ; 95 \% \mathrm{CI}$ : 0.49 to 0.71 ). 
Table 2. Prevalence and prevalence ratio (PR) of underweight (BMI $<22 \mathrm{~kg} / \mathrm{m}^{2}$ ) among older adults according to socio-demographic characteristics. Vigitel Survey, Brazil, 2014.

\begin{tabular}{|c|c|c|c|c|c|}
\hline Variables & $\mathbf{n}$ & $\%$ & p-value ${ }^{a}$ & $\mathrm{PR}_{\text {crude }}(95 \% \mathrm{CI})$ & $\mathrm{PR}_{\text {adjusted }}(95 \% \mathrm{CI})$ \\
\hline Geographic region & & & 0.024 & & \\
\hline South & 1433 & 13.8 & & 1 & 1 \\
\hline Central West & 1398 & 15.8 & & $1.15(0.91-1.45)$ & $1.18(0.94-1.49)$ \\
\hline Northeast & 2592 & 19.0 & & $1.38(1.13-1.69)$ & $1.42(1.17-1.74)$ \\
\hline North & 1512 & 15.4 & & $1.12(0.87-1.44)$ & $1.16(0.90-1.49)$ \\
\hline Southwest & 1482 & 14.5 & & $1.05(0.83-1.34)$ & $1.08(0.85-1.37)$ \\
\hline Gender $^{\mathrm{b}}$ & & & 0.001 & & \\
\hline Male & 2645 & 12.5 & & 1 & 1 \\
\hline Female & 5772 & 17.8 & & $1.41(1.14-1.75)$ & $1.39(1.12-1.72)$ \\
\hline Age (in years) ${ }^{c}$ & & & 0.004 & & \\
\hline 65 to 69 & 2945 & 13.6 & & 1 & 1 \\
\hline 70 to 74 & 2284 & 15.0 & & $1.11(0.85-1.44)$ & $1.10(0.84-1.42)$ \\
\hline 75 to 79 & 1622 & 14.5 & & $1.07(0.80-1.43)$ & $1.08(0.81-1.42)$ \\
\hline 80 or more & 1566 & 21.2 & & $1.56(1.22-2.00)$ & $1.51(1.18-1.93)$ \\
\hline Skin color & & & 0.996 & & \\
\hline White & 4069 & 14.4 & & 1 & 1 \\
\hline Brown & 1867 & 14.7 & & $0.98(0.67-1.42)$ & $0.99(0.69-1.41)$ \\
\hline Black & 598 & 14.1 & & $1.02(0.79-1.31)$ & $1.07(0.84-1.38)$ \\
\hline Yellow/Indigenous & 284 & 15.0 & & $1.04(0.63-1.71)$ & $1.12(0.70-1.79)$ \\
\hline Marital status & & & 0.033 & & \\
\hline Married/Stable union & 3702 & 13.7 & & 1 & 1 \\
\hline Single & 941 & 17.7 & & $1.29(0.96-1.73)$ & $1.12(0.83-1.50)$ \\
\hline Widowed & 2826 & 18.2 & & $1.33(1.07-1.66)$ & $1.07(0.84-1.36)$ \\
\hline Separated/divorced & 807 & 16.1 & & $1.17(0.84-1.63)$ & $1.11(0.80-1.53)$ \\
\hline Schooling & & & 0.452 & & \\
\hline 0 to 8 & 4819 & 16.0 & & 1 & 1 \\
\hline 9 to 11 & 2026 & 15.7 & & $0.98(0.79-1.23)$ & $1.00(0.80-1.25)$ \\
\hline 12 or more & 1572 & 13.4 & & $0.84(0.62-1.13)$ & $0.88(0.66-1.18)$ \\
\hline
\end{tabular}

The influence of context was identified in the multilevel analysis, as the random effect was significant in all models. The prevalence of underweight was significantly higher in the northeastern region when compared to the southern region after the adjustment for the individual factors.

\section{Discussion}

In the present study, the prevalence of underweight among older adults was estimated according to socio-demographic characteristics, health behaviors and morbidity in the different regions of Brazil and factors associated with underweight were identified. Higher prevalence rates were found among women, individuals aged 80 years or older, smokers and those who reported consuming beans, whereas lower prevalence rates were found among those who reported binge drinking and hypertension. Moreover, the prevalence of underweight among older adults was higher in the northeastern region of the country.

The fact that underweight was more prevalent among older women differs from data described by Pereira et al. ${ }^{6}$, who found a higher prevalence rate among male older adults (BMI < $22 \mathrm{~kg} / \mathrm{m}^{2}$ ) in the Brazilian Household Budget Survey (Pesquisa de Orçamentos Familiares, 20082009). Other studies report a lower mean BMI among male older adults in relation to women in different locations of Brazil ${ }^{14,15}$. In contrast, the National Health Survey (Pesquisa Nacional de Saúde - PNS) found a greater prevalence of 
Table 3. Prevalence and prevalence ratio (PR) of underweight $\left(\mathrm{BMI}<22 \mathrm{~kg} / \mathrm{m}^{2}\right)$ among older adults according to health-related behaviors, frequency of food intake, self-rated health and self-reported conditions. Vigitel Survey, Brazil, 2014.

\begin{tabular}{|c|c|c|c|c|c|}
\hline Variables & n & $\%$ & p-value ${ }^{a}$ & $\mathrm{PR}_{\text {crude }}(95 \% \mathrm{CI})$ & $\mathrm{PR}_{\text {adjusted }}(95 \% \mathrm{CI})$ \\
\hline Tobacco use & & & 0.307 & & \\
\hline Non-smoker & 4983 & 15.0 & & 1 & 1 \\
\hline Ex-smoker & 2894 & 15.6 & & $1.04(0.84-1.28)$ & $1.20(0.98-1.48)$ \\
\hline Current smoker & 540 & 19.8 & & $1.32(0.91-1.90)$ & $1.59(1.10-2.27)$ \\
\hline Binge drinking & & & 0.003 & & \\
\hline No & 8091 & 15.9 & & 1 & 1 \\
\hline Yes & 326 & 7.6 & & $0.48(0.29-0.80)$ & $0.58(0.34-0.97)$ \\
\hline Practice of physical activity & & & 0.945 & & \\
\hline Active & 5487 & 15.6 & & 1 & 1 \\
\hline Inactive & 2930 & 15.5 & & $0.99(0.81-1.21)$ & $0.93(0.76-1.14)$ \\
\hline \multicolumn{6}{|l|}{ Food consumption } \\
\hline Regular consumption of Vegetables & 4961 & 16.3 & 0.261 & $1.12(0.92-1.35)$ & $1.07(0.88-1.30)$ \\
\hline Fruit & 6486 & 15.2 & 0.346 & $0.90(0.73-1.12)$ & $0.84(0.68-1.04)$ \\
\hline Fruit and vegetables & 4188 & 15.2 & 0.597 & $0.95(0.78-1.15)$ & $0.90(0.74-1.09)$ \\
\hline Consumption of fatty meats & 846 & 15.8 & 0.929 & $1.01(0.73-1.42)$ & $1.13(0.81-1.57)$ \\
\hline Consumption of chicken with skin & 869 & 12.9 & 0.222 & $0.81(0.57-1.14)$ & $0.87(0.61-1.23)$ \\
\hline Consumption of whole milk & 3692 & 16.3 & 0.366 & $1.09(0.90-1.32)$ & $1.14(0.94-1.37)$ \\
\hline Regular consumption of beans & 4756 & 16.5 & 0.135 & $1.16(0.95-1.41)$ & $1.24(1.02-1.50)$ \\
\hline $\begin{array}{l}\text { Habit of regularly replacing main } \\
\text { meals with snacks }\end{array}$ & 2329 & 14.2 & 0.228 & $0.88(0.72-1.08)$ & $0.83(0.68-1.01)$ \\
\hline Self-rated health & & & 0.641 & & \\
\hline Very good/good & 4289 & 16.0 & & 1 & 1 \\
\hline Fair & 3190 & 14.6 & & $0.91(0.74-1.12)$ & $0.89(0.72-1.09)$ \\
\hline Poor/very poor & 613 & 15.2 & & $0.95(0.67-1.34)$ & $0.91(0.64-1.28)$ \\
\hline \multicolumn{6}{|l|}{ Reported conditions } \\
\hline Arterial hypertension & 5029 & 12.0 & $<0.001$ & $0.57(0.47-0.70)$ & $0.55(0.45-0.66)$ \\
\hline Diabetes mellitus & 1825 & 11.8 & 0.011 & $0.70(0.52-0.93)$ & $0.71(0.53-0.94)$ \\
\hline Dyslipidemia & 3119 & 12.7 & 0.004 & $0.74(0.60-0.91)$ & $0.73(0.59-0.89)$ \\
\hline
\end{tabular}

$\mathrm{n}$ : number of individuals in unweighted sample; ${ }^{\mathrm{a}} \mathrm{p}$-value of Rao-Scott test; PRadjusted: prevalence ratio adjusted for gender and age.

malnutrition $\left(\mathrm{BMI}<18.5 \mathrm{~kg} / \mathrm{m}^{2}\right)$ among women aged 65 to 74 years $(3.3 \%)$ in comparison to men $(2.4 \%)^{16}$. Unlike the previously cited studies, this investigation considered individuals aged 65 years or older. Differences in proportion become more striking between of men and women beginning at this age.

In a study conducted in the city of Viçosa (southeastern Brazil), older women had a higher BMI in comparison to older men, whereas no statistically significant difference was found with regard to underweight ${ }^{17}$. In the municipality of Bambuí (southeastern Brazil), the prevalence of underweight increased with age in both genders, reaching an odds ratio of 2.5 (95\%CI: $1.5-4.0)$ in the $\geq 80$-year-old category ${ }^{15}$. The population aged
80 years or older has grown the most in recent ye$\operatorname{ars}^{18}$. This group is mainly represented by women and the relationship between underweight and age could partially explain the greater proportion of underweight in the female gender. Indeed, sampling bias can occur in cross-sectional studies as a function of the duration of the disease/characteristic studied, since the differentiated chances of the inclusion of individuals in a study could lead to an overestimation of the association.

In the present study, underweight was more prevalent among smokers, which is in agreement with data found in the literature ${ }^{7,19,20}$. Analyzing 1954 individuals aged 60 years or older in four areas of the state of São Paulo, Zaitune et al. ${ }^{19}$ found a $90 \%$ higher prevalence rate of underwei- 
Table 4. Multilevel analysis of factors associated with underweight in older adults (BMI $\left.<22 \mathrm{~kg} / \mathrm{m}^{2}\right)$. Vigitel Survey, Brazil, 2014.

\begin{tabular}{|c|c|c|c|}
\hline Variables/categories & $\mathrm{PR}_{\text {adjusted }}^{\mathrm{a}}(95 \% \mathrm{CI})$ & $\mathrm{PR}_{\text {adjusted }}^{\mathrm{b}}(95 \% \mathrm{CI})$ & $\mathrm{PR}_{\text {adjusted }}^{\mathrm{c}}(95 \% \mathrm{CI})$ \\
\hline \multicolumn{4}{|l|}{ 1st level: context } \\
\hline \multicolumn{4}{|l|}{ Geographic region } \\
\hline South & & & 1 \\
\hline Central West & & & $1.17(0.93-1.49)$ \\
\hline Northeast & & & $1.43(1.17-1.74)$ \\
\hline North & & & $1.20(0.93-1.55)$ \\
\hline Southeast & & & $1.06(0.84-1.35)$ \\
\hline \multicolumn{4}{|l|}{ 2nd level: individual } \\
\hline \multicolumn{4}{|l|}{ Gender } \\
\hline Male & 1 & & \\
\hline Female & $1.32(1.05-1.65)$ & & \\
\hline \multicolumn{4}{|l|}{ Age group } \\
\hline 65 to 69 & 1 & & \\
\hline 70 to 74 & $1.11(0.85-1.44)$ & & \\
\hline 75 to 79 & $1.08(0.80-1.46)$ & & \\
\hline 80 ore more & $1.54(1.19-2.00)$ & & \\
\hline \multicolumn{4}{|l|}{ Tobacco use } \\
\hline Non-smoker & & 1 & \\
\hline Ex-smoker & & $1.22(1.00-1.49)$ & \\
\hline Current smoker & & $1.45(1.01-2.09)$ & \\
\hline \multicolumn{4}{|l|}{ Binge drinking } \\
\hline No & & 1 & \\
\hline Yes & & $0.58(0.34-0.96)$ & \\
\hline \multicolumn{4}{|l|}{ Regular consumption of beans } \\
\hline No & & 1 & \\
\hline Yes & & $1.23(1.02-1.49)$ & \\
\hline \multicolumn{4}{|c|}{ Self-reported arterial hypertension } \\
\hline No & & 1 & \\
\hline Yes & & $0.59(0.49-0.71)$ & \\
\hline
\end{tabular}

ght among smokers. Studies have attributed the association between underweight and tobacco in older adults to the action of nicotine, which can increase adrenergic activity, with a consequent increase in energy expenditure that contributes to a reduction in body weight. Moreover, the release of dopamine and serotonin promoted by nicotine affect the control and regulation of appetite and satiety in the hypothalamus ${ }^{19,21}$. Tobacco dependence is recognized as a chronic condition. Even in older adults, quitting smoking can reduce the risk of becoming ill, improve the control of preexisting diseases, increase one's life expectancy and improve quality of life $\mathrm{e}^{22}$. Encouraging older adults without diseases to quit smoking has the potential to reduce the risk of the development of diseases and improve quality of life, besides to emphasizing the adoption of a healthy lifestyle as an important strategy in the relationship between smoking and BMI.

The relationship between underweight/ malnutrition and alcohol abuse is described in the literature ${ }^{23}$. It is estimated that alcohol abuse contributed to $5.9 \%$ of deaths worldwide in 2012, which occurred mainly due to heart disease and diabetes (33.4\%), gastrointestinal disease $(16.2 \%)$ and malignant tumors in various sites $(12.5 \%)^{24}$. Data from the 2013 National Health Survey indicate a decrease in the prevalence of alcohol abuse with the increase in age, dropping from $5.9 \%$ among individuals aged 60-69 years to $2.0 \%$ among those aged 70 years or older ${ }^{25}$. Des- 
pite the consumption reduces with the increase in age, the elderly people usually drinks alcoholic beverages with more often than younger adults and have less capacity to metabolize alcohol ${ }^{26}$.

The Vigitel questionnaire addresses abusive alcohol intake or binge drinking, which is a type of consumption more associated with young people at times of celebration and other social activities. As the determination of alcohol dependence is not the objective of the Vigitel survey, this type of consumption (binge drinking) may be found among healthy older adults, which could explain the finding of binge drinking as a protective factor against being underweight. A study conducted in the city of Campinas, Brazil, reports a similar finding, as alcohol use once a week was associated with aspects of happiness and a good assessment of one's health status ${ }^{27}$. However, there is ample evidence that alcohol use, particularly binge drinking, increases the risk of accidents and violence ${ }^{28}$ and has harmful consequences for the gastrointestinal system, such as gastritis, diarrhea and poor nutrient absorption ${ }^{23}$, which can further aggravate weight loss/malnutrition in older adults. It should be stressed that the study only identified surviving individuals and their current level of exposure. Moreover, elderly individuals, who are more vulnerable to complications stemming from alcohol abuse, have a greater probability of dying prematurely.

The prevalence of underweight was higher among individuals who reported regularly consumed beans ( $\geq 5$ days per week). A similar finding was reported in a study that analyzed Vigitel data from 2006 to 2009, as a greater occurrence of regular bean intake was found in adults considered underweight or within the ideal weight range $\left(\mathrm{BMI}<25 \mathrm{~kg} / \mathrm{m}^{2}\right)^{29}$. In Brazil, data from national surveys indicate a trend toward the lower consumption of legumes, especially in segments of the population with a higher income and schooling $^{29,30}$. Even with this change, however, beans remain among the five most consumed food items in the country and, combined with rice, constitute an important low-cost source of nutrients ${ }^{31}$. The greater consumption of beans among underweight older adults may partially be explained by the fact that this is a central food in the Brazilian diet that is economically accessible and culturally recognized as providing the body with strength, satiety and endurance ${ }^{32}$.

Hypertension was less prevalent among underweight older adults in the present study, which is in agreement with data reported in a previous study ${ }^{7}$. Ageing is accompanied by changes in vascular properties, such as hardening of the arteries, which plays an important role in the onset and progression of arterial hyperten$\operatorname{sion}^{33}$. Indeed, hypertension is highly prevalent in the elderly population and its association with overweight/obesity, among other cardiovascular diseases, is widely described in the literature ${ }^{34,35}$, independently of the anthropometric indicator employed ${ }^{36}$. In a meta-analysis, Neter et al. ${ }^{37}$ found a mean reduction of $1.05 \mathrm{mmHg}$ in systolic pressure and $0.92 \mathrm{mmHg}$ in diastolic pressure for every one-kg reduction in body weight, independently of age, sex or race.

The five geographic regions of Brazil differ significantly in terms of size as well as social, economic and cultural aspects. The distribution of older adults is also unequal among the regions and differs significantly between urban and rural areas ${ }^{6}$. The ageing of the population is also influenced by regional diversity and imbalances, especially socioeconomic inequalities ${ }^{38}$. Socioeconomic status is an important aspect of quality of life and determines access to a healthy diet. Moreover, the ageing population has begun more recently in the northern and northeastern regions of the country ${ }^{39}$.

Underweight among older adults is a complex, multidimensional phenomenon. This complexity stems from different physiological and pathological changes that are characteristic of the ageing process itself. Lifestyle, socioeconomic determinants inherent to the surrounding context, life history and structural aspects of the environment exert a direct influence on the nutritional status of older adults ${ }^{40}$. The adjustment of a multilevel model consists of integrating individual and contextual factors in epidemiologi$\mathrm{cal}$ analyses. This is founded on the concept that individuals in the same context tend to exhibit more similar attitudes and behaviors than those from different communities/locations. The aim of this line of thinking is to understand how individual and contextual variables interrelate in the determination of health outcomes, seeking to understand how individual and contextual variables are related in the determination of health outcomes $^{41}$.

The present study has limitations that should be considered. The sample was restricted to individuals with a landline telephone at the time of the study, for which less coverage is found in the northern and northeastern regions of the country. In metropolitan areas of the southern, southeastern and central western regions, where telephone coverage is more than $70 \%$, the bias 
stemming from the exclusion of homes without a landline telephone can be considered negligi$b^{42}$. The statistical weights used by Vigitel partially correct differences between populations with and without a landline telephone ${ }^{43}$. The post-stratification weight of each individual in the 2014 Vigitel sample was calculated using the rake method, which involves iterative procedures that consider successive comparisons between estimates of the distribution of each socio-demographic variable in the sample and total population of Brazilian state capitals. Thus, the use of weighting enables estimates to be extrapolated to the whole ${ }^{12}$. Other limitations regard the fact that the data were based on self-reported information and the cross-sectional design does not allow the establishment of a causal relationship, even if one exists. Specifically, the false protective effect of binge drinking against the occurrence of underweight in older adults constitutes an analytical limitation of the cross-sectional design; the ex- posure (alcohol abuse) associated with diseases, such as alcoholism and related conditions, influences the participation of an older adult with the characteristic investigated in the study.

The present results enable estimating the prevalence of underweight among Brazilian older adults in different regions of the country and identifying the epidemiological profile of this condition among older adults who live in capital cities in Brazil. Inequalities were found in the prevalence of underweight among the regions of the country, with the northeastern region affected more by this problem. The findings underscore the importance of organizing health services for the identification, monitoring and recovery of the nutritional status of underweight older adults. Actions developed by health services/workers directed at orienting and supporting families who care for older adults could increase the energy density and nutritional quality of diets, taking the context of the individual into account.

\section{Collaborations}

PMSB Francisco wrote the proposal for the article, performed the literature review, analyzed the data and contributed to the writing of the manuscript. D Assumpção and FSA Borim participated in the writing of the proposal for the article, performed the literature review and contributed to the writing of the manuscript. DC Malta performed a revision of the text and critical analysis of the intellectual content.

\section{Acknowledgments}

Acknowledgment to the Brazilian fostering agencies Conselho Nacional de Desenvolvimento Científico e Tecnológico (CNPq [National Council for Scientific and Technological Development]) for funding the study and Coordenação de Aperfeiçoamento de Pessoal de Nivel Superior (CAPES [Coordination for the Evaluation and Improvement of Higher Education Personnel]) for the post-doctoral grants awarded to D de Assumpção and FSA Borim.

\section{References}

1. Affiune A. Envelhecimento cardiovascular. In: Freitas EV. Tratado de Geriatria e Gerontologia. 2a ed. Rio de Janeiro: Guanabara Koogan; 2006. p. 396-401.

2. Ahmed T, Haboubi N. Assessment and management of nutrition in older people and its importance to health. Clin Interv Aging 2010; 9(5):207-216.

3. Amarya S, Singh K, Sabharwal M. Changes during aging and their association with malnutrition. J Clin Gerontol Geriatr 2015; 6(3):78-84

4. Ferreira LS, Amaral TF, Marucci MFN, Nascimento LFC, Lebrão ML, Duarte YAO. Undernutrition as a major risk factor for death among older Brazilian adults in the community-dwelling setting: SABE survey. Nutrition 2011;27(10):1017-1022

5. Stajkovic S, Aitken EM, Holroyd-Leduc J. Unintentional weight loss in older adults. CMAJ 2011 183(4):443-449.

6. Pereira IFS, Spyrides MHC, Andrade LMB. Estado nutricional de idosos no Brasil: uma abordagem multinível. Cad Saude Publica 2016; 32(5):1-12.

7. Assumpção D, Borim FSA, Francisco PMSB, Neri AL. Fatores associados ao baixo peso em idosos comunitários de sete cidades brasileiras: Estudo FIBRA. Cien Saude Colet 2018; 23(4):1143-1150.

8. Fávaro-Moreira NC, Krausch-Hofmann S, Matthys C, Vereecken C, Vanhauwaert E, Declercq A, Bekkering GE, Duyck J. Risk factors for malnutrition in older adults: a systematic review of the literature based on longitudinal data. Adv Nutr 2016; 7(3):507-522.

9. Flegal KM, Graubard BI, Williamson DF, Gail MH. Excess deaths associated with underweight, overweight, and obesity. JAMA 2005; 293(15):1861-1867.

10. Padwal R, Leslie WD, Lix LM, Majumdar SR. Rela- 
tionship among body fat percentage, body mass index, and all-cause mortality. Ann Intern Med 2016; 164(8):532-541.

11. Coelho Filho JM. Saúde do Idoso. In: Rouquayrol MZ, Silva MGCS. Epidemiologia \& saúde. $7^{\mathrm{a}}$ ed. Rio de Janeiro: MedBook; 2013. p. 401-421.

12. Brasil. Ministério da Saúde (MS). Vigitel Brasil 2014: vigilância de fatores de risco e proteção para doenças crônicas por inquérito telefônico. Brasília: MS; 2015.

13. Lipschitz DA. Screening for nutritional status in the elderly. Prim Care 1994; 21(1):55-67.

14. Barbosa AR, Souza JMP, Lebrão ML, Laurenti R, Marucci MFN. Anthropometry of elderly residents in the city of São Paulo, Brazil. Cad Saude Publica 2005; 21(6):1929-1938.

15. Barreto SM, Passos VMA, Lima-Costa MFF. Obesity and underweight among Brazilian elderly. The Bambuí Health and Aging Study. Cad Saude Publica 2003; 19(2):605-12.

16. Instituto Brasileiro de Geografia e Estatística (IBGE). Pesquisa Nacional de Saúde 2013. Acesso e utilização dos serviços de saúde, acidentes e violências. Rio de Janeiro: IBGE; 2015.

17. Nascimento CM, Ribeiro AQ, Cotta RMM, Acurcio FA, Peixoto SV, Priore SE, Franceschini SCC. Estado nutricional e fatores associados em idosos do $\mathrm{Mu}-$ nicípio de Viçosa, Minas Gerais, Brasil. Cad Saude Publica 2011; 27(12):2409-2418.

18. Lebrão ML, Duarte YAO. Desafios do envelhecimento na reorganização da Sociedade Brasileira. Revista Jurídica Consulex 2009; 304:33-36.

19. Zaitune MPA, Barros MBA, Lima MG, César CLG, Carandina L, Goldbaum M, Alves MCGP. Fatores associados ao tabagismo em idosos: Inquérito de Saúde no Estado de São Paulo (ISA-SP). Cad Saude Publica 2012; 28(3):583-595.

20. Fares D, Barbosa AR, Borgatto AF, Coqueiro RS, Fernandes MH. Fatores associados ao estado nutricional de idosos de duas regiões do Brasil. Rev Assoc Med Bras 2012; 58(4):434-441.

21. Kinnunen T, Haukkala A, Korhonen T, Quiles ZN, Spiro A, Garvey AJ. Depression and smoking across 25 years of the Normative Aging Study. Int. J. Psychiatry Med 2006; 36(4):413-426

22. Viegas CAA. Diretrizes para cessação do tabagismo. $J$ Bras Pneumol 2004; 30(Supl. 2):S2-76.

23. Thorley H, Porter K, Fleming C, Jones T, Kesten J, Marques E, Richards A, Savovi J. Interventions for preventing or treating malnutrition in problem drinkers who are homeless or vulnerably housed: protocol for a systematic review. Syst Rev 2015; 4:131.

24. World Health Organization (WHO). Global status report on noncommunicable diseases 2014. Geneva: WHO; 2014.

25. Garcia LP, Freitas LRS. Consumo abusivo de álcool no Brasil: resultados da Pesquisa Nacional de Saúde 2013. Epidemiol Serv Saúde 2015; 24(2):227-237.

26. World Health Organizations (WHO). Global status report on alcohol and health 2014. Geneva: WHO; 2014.

27. Lima MG, Barros MBA, Alves MCGP. Sentimento de felicidade em idosos: uma abordagem epidemiológica, ISA-Camp 2008. Cad Saude Publica 2012; 28(12):2280-2292.

28. Rehm J, Mathers C, Popova S, Thavorncharoensap M, Teerawattananon Y, Patra J. Global burden of disease and injury and economic cost attributable to alcohol use and alcohol-use disorders. Lancet 2009;
373(9682):2223-2233.

29. Velásquez-Meléndez G, Mendes LL, Pessoa MC, Sardinha LMV, Yokota RTC, Bernal RTI, et al. Tendências da frequência do consumo de feijão por meio de inquérito telefônico nas capitais brasileiras, 2006 a 2009. Cien Saude Colet 2012; 17(12):3363-3370.

30. Levy RB, Claro RM, Mondini L, Sichieri R, Monteiro CA. Distribuição regional e socioeconômica da disponibilidade domiciliar de alimentos no Brasil em 2008-2009. Rev Saude Publica 2012; 46(1):6-15.

31. Souza AM, Pereira RA, Yokoo EM, Levy RB, Sichieri R. Alimentos mais consumidos no Brasil: Inquérito Nacional de Alimentação 2008-2009. Rev Saude Publica 2013; 47(Supl. 1):190S-199S.

32. Canesqui AM. A qualidade dos alimentos: análise de algumas categorias da dietética popular. Rev Nutr 2007; 20(2):203-216.

33. Sociedade Brasileira de Cardiologia/Sociedade Brasileira de Hipertensão/Sociedade Brasileira de Nefrologia. VI Diretrizes Brasileiras de Hipertensão. Arq Bras Cardiol 2010; 95(1 Supl. 1):1-51.

34. Andrade SSA, Stopa SR, Brito AS, Chueri PS, Szwarcwald CL, Malta DC. Prevalência de hipertensão arterial autorreferida na população brasileira: análise da Pesquisa Nacional de Saúde, 2013. Epidemiol Serv Saúde 2015; 24(2):297-304.

35. Zattar LC, Boing AI, Giehl MWC, d'Orsi E. Prevalência e fatores associados à pressão arterial elevada, seu conhecimento e tratamento em idosos no sul do Brasil. Cad Saude Publica 2013; 29(3):507-521.

36. Munaretti DB, Barbosa AR, Marucci MFN, Lebrão ML. Hipertensão arterial referida e indicadores antropométricos de gordura em idosos. Rev Assoc Med Bras 2011; 57(1):25-30.

37. Neter JE, Stam BE, Kok FJ, Grobbee DE, Geleijnse JM. Influence of weight reduction on blood pressure: a meta-analysis of randomized controlled trials. Hypertension 2003; 42(5):878-884.

38. Vasconcelos AMN, Gomes MMF. Transição demográfica: a experiência brasileira. Epidemiol Serv Saúde 2012; 21(4):539-548.

39. Instituto Brasileiro de Geografia e Estatística (IBGE). Pesquisa Nacional por Amostra de Domicílios: síntese de indicadores 2014. Rio de Janeiro: IBGE; 2015.

40. Ferreira AA, Menezes MFG, Tavares EL, Nunes NC, Souza FP, Albuquerque NAF, Pinheiro MAM. Estado nutricional e autopercepção da imagem corporal de idosas de uma Universidade Aberta da Terceira Idade. Rev Bras Geriatr Gerontol 2014; 17(2):289-301.

41. Diez-Roux AV. Multilevel analysis in public health research. Annu Rev Public Health 2000; 21:171-192.

42. Bernal R, Silva NN. Cobertura de linhas telefônicas residenciais e vícios potenciais em estudos epidemiológicos. Rev Saude Publica 2009; 43(3):421-426.

43. Francisco PMSB, Barros MBA, Segri NJ, Alves MCGP. Comparação de estimativas de inquéritos de base populacional. Rev Saude Publica 2013; 47(1):60-68.

Artigo apresentado em 22/05/2017

Aprovado em 28/09/2017

Versão final apresentada em 30/09/2017 